\title{
A simple and established method of tissue culture of human gingival fibroblasts for gingival augmentation
}

\author{
Jolanta Saczko $^{1}$, Marzena Dominiak ${ }^{2}$, Julita Kulbacka ${ }^{1}$, Agnieszka Chwilkowska ${ }^{1}$, \\ Honorata Krawczykowska ${ }^{3}$
}

${ }^{1}$ Department of Medical Biochemistry, Wroclaw Medical University, Wrocław, Poland

${ }^{2}$ Department of Dental Surgery, Wrocław Medical University, Wrocław, Poland

${ }^{3}$ Department of Dental Materials, Wrocław Medical University, Wrocław, Poland

\begin{abstract}
Recent advances in tissue engineering technology suggest its application in different medical fields, including periodontology. There are some reports of new non-enzymatic methods of isolating human gingival fibroblast for short-time cultivation in vitro to be used in autologous gingival augmentation. The aim of this study was to obtain a simple and established method of culturing human gingival fibroblasts. The authors developed a recurrent method that can be successfully used in autologous gingival augmentation.
\end{abstract}

Key words: Gingival fibroblasts - Culture - Periodontology

\section{Introduction}

Regenerative medicine, therapeutic cloning, stem cell research, and tissue engineering are the most exciting areas of medical study and practice in the new millennium. Tissue engineering technology is already being developed and applied in different medical fields to replace cartilage, bone, and cardiovascular components, as well as the pancreas and skin [1,2]. Based on this knowledge, tissue engineering technology may also be applied in periodontology.

A condition for the proper functioning of the mucogingival complex is a suitable width $(\geq 3 \mathrm{~mm})$ and depth $(\geq 0.75 \mathrm{~mm})$ of keratinized gingival epithelium. This facilitates control of the level of plaque, thus preventing the development of periodontal inflammation, and is a form of protection from micro- and macro-trauma to the marginal gingiva, preventing the appearance of gingival recession and all the consequences connected with it, which includes making prosthetic, implant, periodontological, preservative, and orthodontic procedures difficult [3,4]. Proper thickness and width of the keratinized gingiva both have impact on correct tissue healing during regenera-

Correspondence: J. Saczko, Dept. of Medical Biochemistry, Wrocław Medical University, Chałubińskiego Str. 10, 50-368 Wrocław, Poland; tel.: (+4871) 7841375,

e-mail:michal@bioch.am.wroc.pl tive and plastic surgery of the alveolar process, enable undertaking nonsurgical therapy of receding gingiva, and are a condition for selecting a suitable therapeutic procedure in the surgical treatment of recession, e.g. connective tissue graft (CTG), free gingival graft (FGG), and guided tissue regeneration (GTR) $[1,5,6]$. It is also a basic condition for periodontal cosmetic surgery, a field which has gained in significance in recent years $[1,7,8]$.

The role of connective tissue in epithelial keratinization was presented in 1978 by Karing et al. They showed that the connective tissue underlying the gingival epithelium determines its differentiation. In spite of this, some authors believe that the connective tissue lying deeply on the palate may not assure full keratinization of the developing upper epithelium [9]. That is also why in methods of augmenting soft tissue of the alveolar process we distinguish 1) free connective tissue grafts of full and partial thickness and 2) pendunculated connective tissue grafts, e.g. with the rolled patch technique [1]. Fundamental limitations of these types of procedure are the necessity to create a second operating field on the hard palate or on the alveolar

Abbreviations: DMEM - Dulbecco's modified Eagle's medium, FCS - fetal calf serum, HA - hyaluronic acid, PBS - phosphatebuffered saline 
process, the poor color matching to the surrounding tissue with epithelial-connective tissue grafts, the extensive wound on the palate with large grafts, and the postsurgical pain at the donor site. The greatest problem, however, is the limitation in obtaining a sufficient amount of connective tissue for extensive augmentative procedures or for covering several gingival recessions. After taking the graft from the palate, as much as six months' time is necessary for full tissue regeneration at the site. This considerably extends the time and discomfort of the patients' treatment.

Studies by Simain-Sato et al. on animals in 1999 and by Pini Prato et al. on humans in $2000[10,11]$ described the possibility of culturing connective tissue from a small fragment of autologous host tissue. This method allows achieving gingival augmentation 1) with reducing the size of the donor site to a minimum (ca. $2 \times 2 \mathrm{~mm}$ ) and with a large operational field within a period of 10 days and 3) with minimal discomfort to the patient. This also results in an increase in the width of the keratinized gingival epithelium [10]. The aim of this study was to establish a simple method of culturing human gingival fibroblast for use in gingival augmentation.

\section{Material and methods}

The procedure consisted of two different phases: gingival biopsy and cell isolation and cultivation.

Gingival biopsy. Healthy human gingival tissue was obtained from 10 patients undergoing extraction. The gingival biopsies were obtained from the Department of Dental Surgery of Wroclaw Medical University. The experiments were conducted in accordance with the requirements of the Bioethics Commission of Wroclaw Medical University.

Before surgery, the tissue was washed with boric acid, which protects from mycological infection. Under local anesthesia, a small portion $(2 \times 1 \times 1 \mathrm{~mm})$ of gingiva was removed from the gum using a scalpel. The tissue was placed in a nutritional medium (Dulbecco's modified eagle medium, DMEM) containing 10\% fetal calf serum (FCS), and antibiotics (penicillin $100 \mathrm{IU} / \mathrm{ml}$, streptomycin $100 \mu \mathrm{g} / \mathrm{ml}$, and amphotericin B $100 \mu \mathrm{g} / \mathrm{ml}$ ) and taken to the cell culture laboratory.

Isolation and culture of human gingival fibroblasts. Upon arrival at the laboratory, the tissue was rinsed in sterile phosphatebuffered saline (PBS, $\mathrm{pH}=7.4$ ) and transferred to a Petri dish containing DMEM. The tissue was minced mechanically using scissors and a scalpel. The obtained suspension of tissue fragments and fibroblast cells was condensed by centrifugation $(200 \times \mathrm{g}$ for 5 $\mathrm{min})$. The resuspended pellet was placed in plastic bottles in culture medium (DMEM) containing 10\% FCS penicillin/streptomycin and amphotericin B $100 \mu \mathrm{g} / \mathrm{ml}$. Monolayer cultures were incubated in conventional growth medium as described above at 37 $\mathrm{C}$ in an incubator containing humidified air $\left(5 \% \mathrm{CO}_{2}\right)$. The medium was renewed every two days. The human gingival fibroblasts were confluent after 5-7 days of culture. Cell numbers were determined using a Bürcker's chamber and their viability was assessed by the trypan blue exclusion test After this the cells were incubated with trypsin $(0.05 \%)$ for 5 minutes. The isolated gingival fibroblasts were then centrifuged at $200 \times \mathrm{g}$ for $5 \mathrm{~min}$ and resuspended on Petri dishes on a special carrier (resorbable bilayer membrane for periodontal tissue regeneration: Bio-Glide ${ }^{\circledR}$ Perio Geistlich Biomaterials ). Cells are grown on this material for only three days; after this time it should be used for surgical procedures.

\section{Results}

Human gingival fibroblasts were successfully cultured from all the 10 biopsies collected from gingival tissue. After about two days of growth, the cells formed small groups consisting of fibroblast-like cells (Fig. 1) and after 5-7 days a full monolayer of non-overlapping cells was obtained (Fig. 2). The cell concentration was determined by placing the cells in a Bürcker's chamber under a microscope. The number of cells within a defined area was counted and the cell concentration was then calculated. The trypan blue exclusion test after typsinizsation showed that $97 \%$ to $99 \%$ of the cells were viable. The human gingival fibroblasts did not exhibit multi-polarity very significantly throughout the culture and were spread within the plastic culture bottles. Under phase-contrast microscopy they presented as spindle-shaped cells with the elongated appearance typical of fibroblast cells (Fig. 2). The isolated human gingival fibroblasts grew on the resorbable bilayer membrane (Fig. 3).

\section{Discussion}

In the last decades there have been great advances in tissue engineering technology. This has led to its application in different medical fields, also in periodontology. There are some reports of new non-enzymatic methods used in autologous gingival augmentation. Here we describe a simple and established method of primary tissue culture of human gingival fibroblasts used in autologous gingival augmentation. The first step of this study was the isolation of human gingival fibroblasts from a small biopsy sample $\left(2 \times 1 \times 1 \mathrm{~mm}^{3}\right)$ and then enhancing the efficiency of this culture in vitro. The cells were only isolated mechanically and cultured in DMEM supplemented with 10\% FCS and penicillin $(100 \mathrm{IU} / \mathrm{mI})$, streptomycin $(100 \mathrm{~g} / \mathrm{ml})$, and amphotericin B $(100 \mu \mathrm{g} / \mathrm{ml})$. Similarly to our methods, Simalin-Safo et al. [11], in an in vitro preliminary study of rat gingival fibroblasts, used samples of epithelial connective tissue $(2 \times 2 \times 2 \mathrm{~mm})$ in DMEM with $20 \% \mathrm{FBS}$ and penicillin $(100 \mathrm{IU} / \mathrm{ml})$, and streptomycin $(100 \mu \mathrm{g} / \mathrm{ml})$, but without amphotericin B. It is very important to use amphotericin B because it protects the cells against mycological infection.

In contrast to our investigation, Prato isolated human fibroblast enzymatically with dispase (5 $\mathrm{mg} / \mathrm{ml}$ ). The fibroblasts were seeded onto a threedimensional scaffold of benzyl ester of hyaluronic acid (HA) [10]. In other methods, fibroblasts were isolated by dispase and collagenase. The cells were cultivated 

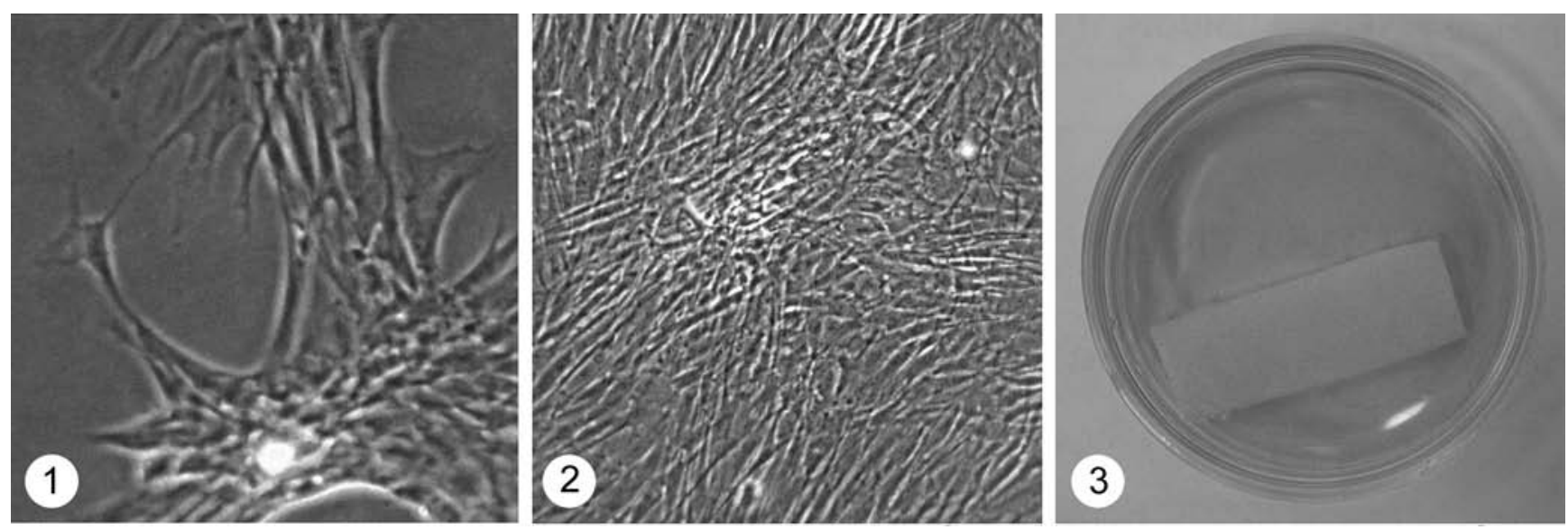

Fig. 1. Human gingival fibroblast-like cells: small groups after two days of culture (phase-contrast microscopy, magnification $\times 176$ ). Fig. 2. Human gingival fibroblast-like cells: full monolayer after seven days of culture. (phase-contrast microscopy, magnification $\times 176$ ). Fig. 3. Isolated gingival human fibroblasts grown on a resorbable bilayer membrane (magnification $\times 4$ ).

in a recombinant collagen sponge [12]. Earlier methods of gingival fibroblast isolation and culture involved very specific enzymes for cell separation. A full cell monolayer was obtained after 10 to 14 days [13]. Our method is based on mechanical cell separation and cell culture and a full cell monolayer is obtained in 5 to 7 days.

The tissue engineering technique applied in this study may be considered a new gingival augmentation procedure. This method of isolating and cultivating human gingival fibroblasts is currently undergoing controlled clinical testing. Preliminary results show that the first autologous augmentations were successful. A patent application for the method described in this paper has been submitted.

Acknowledgements: The authors wish to thank Mateusz Lugowski for help in preparing the manuscript.

\section{References}

[1] Erpenstain H. Chirurgia plastyczna przyzębia - przegląd. Quintess. dla lek stom (Polish). 2000;8:325-344.

[2] Malekzadeh R, Hollinger JO, Buck D, Adams DF, McAliester BS. Isolation of human osteoblast-like cells and in vitro amplification for tissue engineering. J Periodontol. 1998;69: 1256-1262.

[3] Dominiak M, Leśniak P, Łagowska K, Michalska A, Ozga M, Szulgan A. Wczesna i odroczona sterowana regeneracja kości przy usuwaniu zatrzymanych kłów: short communication. Dent Med Probl. 2002;39:151-160.

[ 4] Dominiak M, Zaremba A, Skośkiewicz K, Pyka E, Stępień P. Możliwości pokrycia recesji dziąsła powstałej po chirurgiczno-ortodontycznym leczeniu zębów zatrzymanych przypadków. Dent Med Probl. 2002;39:161-167.
[ 5] Kassolis JD, Bowers GM. Supracrestal bone regeneration. A pilot study. Int J Periodont Restorative Dent. 1999;19:131-139.

[ 6] Salkin LM, Freedman AL, Stein MD, Bassiouny MA. A longitudinal study of untreated mucogingival defects. J Periodontol. 1987;58:164-166.

[7] Hürzeler MB, Dietmar W. Functional and esthetic outcome enhancement of periodontal surgery by application of plastic surgery principles. Int J Periodont Restorative Dent. 1999; 19:37-43.

[ 8] Takei HH, Azzi RA. Newman MG, Takei HH, Carranza FA. Carranza's periodontal plastic and esthetic surgery. Clinical Periodontology. W. B. Saunders Company, Philadelphia, 2002;851-860.

[ 9] Borghetti A, Glise JM, Monnet-Corti V, Dejou J. Comparative clinical study of a bioabsorbable membrane and subepithelial connective tissue graft in treatment of human gingival recession. J Periodontol. 1999;70:123-130.

[10] Pini Prato GP, Rotundo R, Magnani C, Soranzo C. Tissue engineering technology for gingival augmentation procedures: A case report. Int $J$ Periodont Restorative Dent. 2000;20:553-559.

[11] Simian-Safo F, Lahmouzi J, Heinen E et al. Graft of autologous fibroblasts in gingival tissue in vivo after culture in vitro preliminary study in rats. J Periodontol. 1999;34:323-328.

[12] Simalin-Safo F, Lahmouzi E, Helnen E et al. Graft of autologous fibroblast in gingival tissue in vivo after culture in vitro preliminary study on rats. J Periodontol Res. 1999;34:323328.

[13] Yamada K, Yamaura J, Katoh M, Hata K, Okuda K, Yoshie H. Fabrication of cultured oral gingiva by tissue engineering techniques without materials of animal origin. $J$ Periodontol. 2006;77:672-677.

[14] Karring T, Lang NP, Löe H. The role of gingival connective tissue in determining epithelial differentiation. J Periodontol. 1978;10:1-11.

Submitted: 6 September, 2007 Accepted after reviews: 22 December, 2007 